\title{
The men God created to be fathers and mentors
}

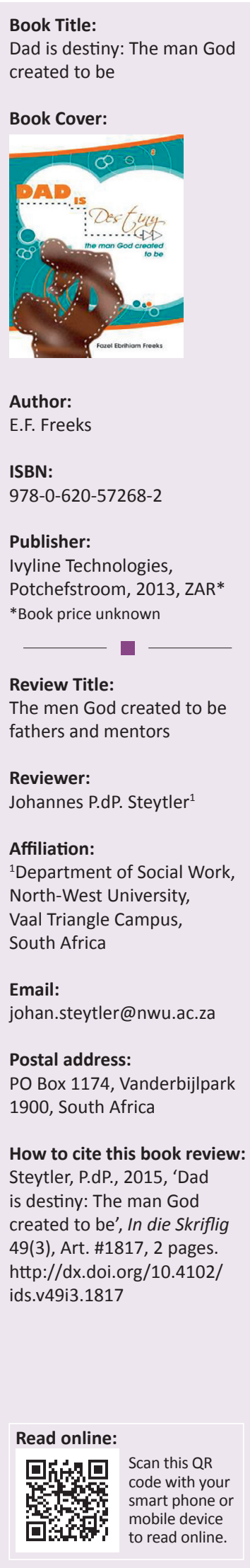

The author of this book focuses on fathers as being mentors for their children. DAD is destiny: The man God created to be is written from a Christian perspective, bringing forth Christian values and norms.

Firstly, Freeks captures the reader's attention by explaining that fathers are currently experiencing a crisis: 'World-wide, fatherhood is in a threatened position and the traditional roles of fathers are being turned upside down' (p. 1). He further elaborates that fathers are becoming more absent in the lives of children, creating a father hunger. Thus, the effects of this absent father not only influence the behaviour pattern of the child, but also the child's perception of God.

In the second chapter of the book, Freeks explains the importance of parenting. He refers to parenting as a higher calling that is much like a double-edged sword: both a relation and an activity. The importance of the father in the development stages of the child in his or her infant, toddler and high-school teenager phases are explained. One misses, however, the pre-teen development phase where children reach puberty and go through the transitional phase from child to teenager. In this chapter, Freeks also indicates a father's role in the child's spiritual faith and Christian life. He lists some responsibilities of a father and the impact of fathering. He also explains his opinion of discipline and punishment in a very interesting way.

Freeks starts to explain mentoring and the importance of it in chapter 4 where he uses biblical figures as examples. Not all biblical examples Freeks uses to explain the mentor relationship, is in a father-son relationship (e.g. Moses and Joshua; Paul, Timothy, Titus and Onesimus), but it seems that the importance of these mentor relationships is built on a relationship with God first. Freeks uses some of arguments that are most likely from an occupational mentoring system, but he manages to link it in a father-son relationship, bringing forth the importance of a mentoring relationship for both the mentor and the mentee. In the same chapter, Freeks points out the relationship between Jesus Christ and his disciples and the mentoring relationship between them. He includes a section on certain outstanding points that played a role in the lives of the disciples where he made a statement that the disciples 'had been given the mystery which is the truth, and the truth is for insiders, not outsiders; in other words, those who walk with Him, stay close to and follow Him'. It is unclear what Freeks means with the mystery and how that relates to a mentoring relationship between a father and his son.

In chapter 5, Freeks explains and defines values. It is interesting to find him explaining values at this point of the book, as he uses and refers to values from chapter 1 .

In Chapter 6, Freeks jumps back to the father's role where he provides practical guidelines to equip the father to be a dad-of-destiny. He explains the different roles of the father and indicates that the father is the leader of the family. Only at this stage Freeks elaborates that the father and the mother are in partnership when transmitting Christian values.

Dad is destiny: the man God created to be is filled with biblical examples that are embedded in Christian values for men where he elaborates on the father figure as mentor and the importance of a father for his children. Unfortunately, in many of the examples he uses from the Bible, the mentors and the mentees are not family members, which means that worthy mentors do not only have to be the father of the child, but it can also be somebody outside the family system. Freeks repeats certain topics in the book on several occasions, making it sometimes difficult to follow these topics. Chapter 5, which explains values between two topics that focus on 
mentoring and mentoring relationships, tends to confuse the reader and it leaves the impression that the book was not well-planned. Freeks lists several authors in the reference list, but nowhere in the text does he refer to nor does he acknowledge their studies, thus giving the impression that this book is only of his knowledge base.
This book has been written for the reader to be able to read it with ease and it can help men to understand the importance of a mentoring relationship with their sons. Men who just started with a mentoring relationship can benefit from this reading, as it might help them forming a good foundation of their mentoring relationship. 